\title{
Management of purple blotch and Stemphylium blight of onion in Tarai and Bhabar regions of Uttarakhand, India
}

\author{
Deepa Nainwal* and Karuna Vishunavat \\ Department of Plant Pathology, G.B.P.U.A. and T. Pantnagar-263 145, (Uttarakhand), INDIA \\ *Corresponding author. E-mail: deepanainwalpng@gmail.com \\ Received: May 15, 2015; Revised received: December 31, 2015; Accepted: February 5, 2016
}

\begin{abstract}
Purple blotch [Alternaria porri] (Ellis) Cif.) and Stemphylium blight [Stemphylium vesicarium] (Wallr.) E. Simmons) of onion cause serious problems in onion seed crop in Tarai and Bhabar region of Uttarakhand. In present study different bio agents and fungicides have been evaluated in vivo against both the diseases. The severity of both purple blotch and Stemphylium blight varied in both Tarai and Bhabar region and even more pronounced in Tarai region than in Bhabar region. A correlation was observed in between the severity of both the diseases with the yield in seed crop. The minimum disease severity of purple blotch and stemphylium blight with the foliar spray of mancozeb (@ 0.3\%)+ monochrotophos (@ 0.05\%) were observed 2.67\% and 2.57\% respectively with the total yield of seed was $1844.44 \mathrm{~kg} / \mathrm{ha}$ over check $893.33 \mathrm{~kg} / \mathrm{ha}$ in 2011 . While with the foliar spray of neembicidine (@ $0.3 \%$ ) disease severity of both the diseases were $5.57 \%$ and $4.78 \%$ respectively providing a yield of $1827.78 \mathrm{~kg} / \mathrm{ha}$ in seed crop of onion in 2011. Amongst the applied bio-agents, the foliar spray of Trichoderma harzianum (@ 1\%) the disease severity of purple blotch and stemphylium blight were recorded $15.44 \%$ and $13.11 \%$ respectively which was found to be most effective in delaying the disease appearance and providing a yield of $1134.44 \mathrm{~kg} / \mathrm{ha}$ in 2011 . However, all the treatments helped to reduce both the diseases in comparison with check.
\end{abstract}

Keywords: Alternaria porri, Bio-agents, Onion, Purple blotch, Stemphylium blight.

\section{INTRODUCTION}

Onion a member of Amaryllidaceae belongs to genus Allium. It (Allium cepa L.) is an extremely important vegetable crop not only for consumption but also as the highest foreign exchange earner among the vegetables. It has gained the importance of a cash crop rather than vegetable crop because of its very high export potential. The productivity of onion can be affected by number of factors including diseases. Wherever, diseases play an important role in reduction of production and quality. Seed is a basic and vital input and decides the commercial success of a crop variety. For the past few years purple blotch is spreading in epiphytotic proportions in areas wherever onion is being grown. The disease has international dimensions and has an epidemic form in the year 2013 in West Pokot, District Rift Valley, Kenya (Source: Business Daily, Kenya: Rift Valley, 2013). In India, the diseases caused by unseasonal rains have ruined almost 70 per cent of the kharif onion crop in Maharashtra in 2010, which is responsible for the nationwide shortage of the commodity (Shrivastava, 2010). The two important leaf blight diseases purple blotch and Stemphylium blight commonly affect onion crop in almost all onion growing pockets causing considerable damage to the crops (Mathur and Sharma, 2006). The plentiful harvest could be achieved only with seeds having quality stan- dards of purity, germination, uniformity in weight and size apart from freedom from pest and diseases (Tomar and Negi, 2002).

Aveling et al. (1993) have also found that $S$. vesicarium in conjuction with $A$. porri has been reported as one of the destructive foliar and seed stalk pathogens of onion under warm and moist conditions. The low productivity of onion was attributed to infestation by onion thrips along with these pathogens. Gupta et al. (1994) found Stemphylium blight and purple blotch as diseases of national importance. Gupta and Pathak (1998) reported that the yield losses in both bulb and seed crop due to these diseases under favorable conditions may go upto $96 \%$ in India. Suheri and Price (2000) found A. porri and $S$. vesicarium, as potentially important pathogens of winter grown onion crops and found purple leaf blotch symptoms as a complex caused by both the pathogens. Thrips play an important role in enhancing crop losses and aggravate the disease incidence (Lawande et al., 2011).

In Northern India, the purple blotch and Stemphylium blight are two most important diseases, which cause considerable losses in bulbs and seed crops in onion. Thrips are also known as important agents which aggravate the problem of purple blotch and Stemphylium blight, infection which again reduces the productivity. The injuries made by thrips are found to enhance the invasion of the fungus $A$. porri. Keeping in view the 
problem of purple blotch and Stemphylium blight of onion in Tarai and Bhabar region of Uttarakhand causing enormous losses in seed production, the present study is undertaken to evaluate different bioagents and fungicides for the management of both purple blotch and Stemphylium blight of onion.

\section{MATERIALS AND METHODS}

Field trials were conducted both in tarai and bhabar region of Uttarakhand for two successive years (200910 and 2010-11) during Rabi season on onion seed crop following the Randomized Block Design [RBD] pattern with three replications and twelve treatments. Different bioagents and fungicides were evaluated for their field efficacy against purple blotch and Stemphylium blight of onion. The onion cultivar Agri found Dark Red susceptible to purple blotch was used for the experiment. The trial was conducted in an area of $32.5 \times 9.5 \mathrm{~m}$. The plot size was maintained at $2 \times 1.5 \mathrm{~m}$ keeping row to row distance as $30 \mathrm{~cm}$ and plant to plant distance $25 \mathrm{~cm}$ in three rows@ 8 bulbs per row, and twenty four 24 bulbs per plot. A total of six foliar sprays of different treatments and dosages are given at 15 days interval starting first spray at 75 days after sowing (DAS) in seed crop (Table1).

The disease intensity for purple blotch and Stemphylium blight is rated using 0-5 scale (Sharma, 1986).

$\begin{array}{ll}\begin{array}{l}\text { Rating } \\ \text { number } \\ 0\end{array} & \text { Reaction description } \\ 1 & \text { No disease symptom } \\ 2 & \begin{array}{l}\text { A few spots towards tip covering } 10 \text { per- } \\ \text { cent leaf area }\end{array} \\ & \begin{array}{l}\text { Several purplish brown patches covering } \\ \text { upto } 20 \text { percent of leaf area }\end{array} \\ 3 & \begin{array}{l}\text { Several patches with paler outer zone } \\ \text { covering upto } 40 \text { percent leaf area }\end{array} \\ 4 & \begin{array}{l}\text { Leaf streaks covering upto } 75 \text { percent } \\ \text { leaf area or breaking of the leaves from } \\ \text { center } \\ \text { Complete drying of the leaves or break- } \\ \text { ing of leaves from center }\end{array}\end{array}$

Percent Disease Index (PDI) was calculated using fomula given by Wheeler (1969). The data were statistically analyzed.

$\mathrm{PDI}=\frac{\text { Total sum of numerical rating }}{\text { Numberof observations }} \times \frac{100}{\text { Maximum disease rating }}$

Yield $\mathrm{kg} / \mathrm{plant}$ was recorded and percent increase in yield due to different treatment was calculated using following formula:

Percent increase in yield $=\frac{\text { Yisld in treatment }- \text { Yield in check plot }}{\text { Yield in check plot }} \times 100$

Based on Percent Disease Index, the data of two years (2009-10 and 2010-11) on seed yield was pooled and analyzed for each treatment.

\section{RESULTS AND DISCUSSION}

Out of eleven treatments, six foliar spray of mancozeb @ $(0.3 \%)+$ monochrotophos@ (0.05\%) at fortnight interval was found to be the best and significantly superior in reducing diseases intensity and increasing the yield of onion seed crop followed by neembicidine and folicur. In this treatment lowest disease severity was recorded for purple blotch $10.90 \%, 4.67 \%$ and $6.33 \%$, $2.67 \%$ and Stemphylium blight $17.45 \%, 5.78 \%$ and $4.57 \%, 2.57 \%$, respectively in Tarai and Bhabar region during 2010 and 2011. In neembicidine (@ 0.03) treated plot the disease severity was observed for purple blotch $11.90 \%, 7.67 \%$ and $11.57 \%, 5.57 \%$ and Stemphylium blight $18.63 \%, 8.44 \%$ and $10.23 \%$, $4.78 \%$,respectively whereas in check the disease severity was recorded $71.33 \%, 57.33 \%$ and $59.57 \%$, $47.90 \%$ for purple blotch and $82.00 \%, 72.57 \%$ and $53.00 \%, 38.57 \%$, respectively for Stemphylium blight in Tarai and Bhabar region during the same year. The disease severity in folicur treated plot for purple blotch $16.23 \%, 10.23 \%$ and $12.90 \%, 10.00 \%$ and Stemphylium blight $21.90 \%, 12.11 \%$, and $11.60 \%, 8.78 \%$ which was stastically at par. The foliar spray of mancozeb + monochrotophos resulted a highest yield of onion seed $1470 \mathrm{~kg} / \mathrm{ha}, 1755.55 \mathrm{~kg} / \mathrm{ha}$ and $1790 \mathrm{~kg} / \mathrm{ha}$, $1844.44 \mathrm{~kg} / \mathrm{ha}$ followed by neembicidine $1453.33 \mathrm{~kg} / \mathrm{ha}$, $1694.68 \mathrm{~kg} / \mathrm{ha}$ and $1772.22 \mathrm{~kg} / \mathrm{ha}, 1827.78 \mathrm{~kg} / \mathrm{ha}$ and folicur $1436 \mathrm{~kg} / \mathrm{ha}, 1683 \mathrm{~kg} / \mathrm{ha}$ and $1735.56 \mathrm{~kg} / \mathrm{ha}$, $1800 \mathrm{~kg} / \mathrm{ha}$, respectively in Tarai and Bhabar region of Uttarakhand during 2009-2010 and 2010-2011. In check plot the yield of onion seed was recorded $280 \mathrm{~kg} /$ ha, $404.87 \mathrm{~kg} / \mathrm{ha}$ and $873.33 \mathrm{~kg} / \mathrm{ha}, 893.33 \mathrm{~kg} / \mathrm{ha}$ in Tarai and Bhabar during the both consecutive years. It seems that monochrotophos and neembicidine when used either alone or in combination with fungicides reduce the thrips population, which by way of injury to the plant, helped the fungi to invade and increased the diseases severity. Sprays of mancozeb + carbendazim, carbendazim and iprobenfos were found ineffective in management of both purple blotch and Stemphylium blight. The highest disease severity and lowest yield was recorded in control plot as listed (Tables 1 and 2). The results are in the conformity with Vijaya and Rahman (2004) who observed the foliar spray of mancozeb (@0.3\%) with monochrotophos (@0.05\%) was the best treatment and recorded the least diseases incidence and the highest yield. Borkar and Patil (1995) observed that mancozeb reduced the disease intensity by $6 \%$ whereas the yield was increased by $10.99 \%$ and also had a higher cost: benefit ratio than the other fungicides used. Schwartz and Mohan (1995) found that foliar application of folicur, mancozeb, strobilurin fungicides were effective for the management of purple blotch of onion. Wickramaarachchi et al. (2004) also found folicur (@ of $3.5 \mathrm{ml} / 101$ ) to be an effective fungicides in reducing both the diseases and increasing yield. In the present study, the performance of fungicides in reducing disease severity and increasing seed 
Table 1. Effect of different fungicides and bio control agent on the severity of disease Purple blotch and Stemphylium blight (2009-10 and 2010-11).

\begin{tabular}{|c|c|c|c|c|c|c|c|c|c|c|}
\hline \multirow{3}{*}{$\begin{array}{l}\text { S. } \\
\mathbf{N} .\end{array}$} & \multirow{3}{*}{ Treatments } & \multirow{3}{*}{$\begin{array}{l}\text { Doses of } \\
\text { foliar } \\
\text { spray (\%) }\end{array}$} & \multicolumn{4}{|c|}{$\begin{array}{c}\text { Disease severity of Purple } \\
\text { blotch (\%) }\end{array}$} & \multicolumn{4}{|c|}{$\begin{array}{c}\text { Disease severity of Stem- } \\
\text { phylium blight (\%) }\end{array}$} \\
\hline & & & \multicolumn{2}{|c|}{ Tarai region } & \multicolumn{2}{|c|}{ Bhabar region } & \multicolumn{2}{|c|}{ Tarai region } & \multicolumn{2}{|c|}{ Bhabar region } \\
\hline & & & 2010 & 2011 & 2010 & 2011 & 2010 & 2011 & 2010 & 2011 \\
\hline 1 & Pseudomonas flouresence & 1 & 25.33 & 19.44 & 24.44 & 19.11 & 33.44 & 24.33 & 19.90 & 16.44 \\
\hline 2 & Trichoderma harzianum & 1 & 21.11 & 15.93 & 20.33 & 15.44 & 28.00 & 20.33 & 17.23 & 13.11 \\
\hline 3 & P. flouresence $+T$. harzianum & 1 & 37.00 & 28.90 & 27.90 & 22.44 & 46.66 & 32.00 & 24.57 & 20.67 \\
\hline 4 & Iprobenfos & 0.10 & 43.11 & 39.23 & 40.33 & 31.90 & 53.33 & 45.00 & 34.57 & 25.44 \\
\hline 5 & Copperoxychloride & 0.30 & 38.57 & 30.00 & 36.57 & 22.11 & 47.00 & 38.00 & 30.23 & 18.00 \\
\hline 6 & Mancozeb & 0.20 & 31.23 & 22.33 & 26.57 & 18.33 & 40.00 & 32.67 & 24.23 & 15.33 \\
\hline 7 & Carbendazim & 0.10 & 47.23 & 41.23 & 45.67 & 33.67 & 57.66 & 48.33 & 43.00 & 26.00 \\
\hline 8 & Mancozeb + Carbendazim & 0.20 & 52.23 & 47.00 & 51.23 & 36.23 & 59.66 & 52.67 & 48.90 & 31.33 \\
\hline 9 & Monochrotophos + Mancozeb & $0.3+0.05$ & 10.90 & 4.67 & 6.33 & 2.67 & 17.45 & 5.78 & 4.57 & 2.57 \\
\hline 10 & Tebuconazole & 0.10 & 16.23 & 10.23 & 12.90 & 10.00 & 21.90 & 12.11 & 11.60 & 8.78 \\
\hline 11 & Neembcidine & 0.03 & 11.90 & 7.67 & 11.57 & 5.57 & 18.63 & 8.44 & 10.23 & 4.780 \\
\hline 12 & Control & Water & 71.33 & 57.33 & 59.57 & 47.90 & 82.00 & 72.57 & 53.00 & 38.57 \\
\hline \multicolumn{2}{|c|}{ Mean } & & 33.84 & 26.99 & 30.28 & 22.11 & 42.14 & 32.69 & 26.83 & 18.41 \\
\hline \multicolumn{2}{|c|}{$\mathrm{CD}(\mathrm{P}=0.05)$} & & 6.97 & 4.08 & 5.28 & 7.48 & 9.82 & 7.91 & 7.73 & 4.84 \\
\hline \multicolumn{2}{|c|}{$\mathrm{CV}$} & & 12.23 & 9.06 & 10.22 & 19.52 & 13.75 & 14.28 & 17.01 & 15.32 \\
\hline
\end{tabular}

Data based on means of three replications

Table 2. Effect of foliar spray of fungicides and biocontrol agents on the yield of onion seed crop 2009-10 and 2010-11.

\begin{tabular}{|c|c|c|c|c|c|c|}
\hline \multirow{3}{*}{$\begin{array}{l}\text { S. } \\
\text { N. }\end{array}$} & \multirow{3}{*}{ Treatments } & \multirow{3}{*}{ Doses of foliar spray (\%) } & \multicolumn{4}{|c|}{ Yield (kg/ha) } \\
\hline & & & \multicolumn{2}{|c|}{ Tarai region } & \multicolumn{2}{|c|}{ Bhabar region } \\
\hline & & & 2010 & 2011 & 2010 & 2011 \\
\hline 1 & Pseudomonas flouresence & $1 \%$ & 800.11 & 831.47 & 1062.22 & 1116.67 \\
\hline 2 & Trichoderma harzianum & $1 \%$ & 842.22 & 860.12 & 1073.33 & 1134.44 \\
\hline 3 & P. flouresence + T.harzianum & $1 \%$ & 503.33 & 527.99 & 1001.11 & 1056.67 \\
\hline 4 & Iprobenfos & $0.10 \%$ & 563.33 & 587.67 & 1016.67 & 1062.22 \\
\hline 5 & Copperoxychloride & $0.30 \%$ & 494.44 & 502.46 & 927.78 & 1024.44 \\
\hline 6 & Mancozeb & $0.20 \%$ & 626.67 & 671.67 & 1116.67 & 1204.44 \\
\hline 7 & Carbendazim & $0.10 \%$ & 470.00 & 496.15 & 918.89 & 1003.33 \\
\hline 8 & Mancozeb + Carbendazim & $0.20 \%$ & 336.67 & 492.91 & 901.11 & 906.67 \\
\hline 9 & Monochrotophos + Mancozeb & $0.3 \%+0.05 \%$ & 1470.00 & 1755.00 & 1790.00 & 1844.44 \\
\hline 10 & Tebuconazole & $0.10 \%$ & 1436.67 & 1683.12 & 1735.56 & 1800.00 \\
\hline 11 & Neembcidine & $0.30 \%$ & 1453.33 & 1694.68 & 1772.22 & 1827.78 \\
\hline 12 & Control & Water & 280.00 & 404.87 & 873.33 & 893.33 \\
\hline \multicolumn{2}{|c|}{ Mean } & & 773.11 & 875.69 & 1182.41 & 1239.54 \\
\hline \multicolumn{2}{|c|}{$\mathrm{CD}(\mathrm{P}=0.05)$} & & 59.74 & 61.24 & 87.18 & 152.45 \\
\hline \multicolumn{2}{|c|}{$\mathrm{CV}$} & & 4.55 & 4.15 & 4.35 & 7.26 \\
\hline
\end{tabular}

Data based on means of three replications.

production has been shown in Tables 1 and 2 .

Among the bioagents, T. harzianum @ (1\%) was found to be effective in delaying diseases severity with optimum yield $(1134.44 \mathrm{~kg} / \mathrm{ha})$ over check $(893.33 \mathrm{~kg} /$ ha). Similar results on antifungal activity of bioagents has been reported against $A$. porri and S. vesicarium by Vannaci and Harman (1987); Sharma (2012); Shahnaz et al. (2013). Researcher revealed that among biocontrol agents $T$. harzianum was the most effective against $A$. porri. This indicates the foliar spray of bioagents is an important approaches for successful disease management in onion. Bio- control agents T. harzianum, Ps. fluorescence and their combination gave higher level of disease reduction as compared to many other fungicides used (Table-1). The foliar spray of neembicidine was also effective next to mancozeb + monochrotophos in reducing the diseases severity as well as thrips population with increased yield 1827.78 $\mathrm{kg} / \mathrm{ha}$ as compared to check (Table 1). Our results were more similar to Nemane et al. (2001); Singh et al. (2010) that the neem based bio-pesticides were useful in the management of onion thrips. Bandi and Sivasubramanian (2012) suggested the foliar application of Ps. fluorescens to enhance the activity of defense related enzymes which are involved in the production of phytoalexins and phenolics in onion plant and induce plant resistance against $T$. tabaci.

It was also observed that among both the diseases, the crop of Tarai region was more pronounced than Bhabar region and might be correlated with the environmental conditions at both the places. The present study indicates that suitable integration of more efficient 
treatments like fungicides, bioagents in combination with bio-insecticides and insecticides, may provide a better management of the purple blotch and Stemphylium blight of onion (Table 1).

\section{Conclusion}

For the management of diseases the combination of mancozeb + monochrotophos (@0.3\% + 0.05\% respectively), proved to be the most effective among all fungicidal treatments as gave the highest yield of onion seed $1844.44 \mathrm{~kg} /$ ha followed by neembicidine 1827.78 $\mathrm{kg} / \mathrm{ha}$, folicur $1800 \mathrm{~kg} / \mathrm{ha}$ and T. harzianum $1134.44 \mathrm{~kg} /$ ha, respectively as compared to check $893.33 \mathrm{~kg} / \mathrm{ha}$. However, in integrated approach of diseases management under organic crop production, bio-insecticide (neembicidine) and bio-control agent ( $T$. harzianum) may be looked upon as promising alternative for the management of purple blotch and stemphylium blight of onion.

\section{ACKNOWLEDGEMENTS}

Thanks are due to Dr. J. P. Singh (Joint Director, Vegetable Research Centre, G.B.P.U.A. \&T., Pantnagar) and Dr. S. D. Tewari (Professor, Department of Botany, Government Girls Degree College, Haldwani, Uttarakhand) for their help and encouragement while conducting the field experiments in Tarai and Bhabar regions of Uttarakhand. Financial assistance provided by directorate experiment station to conduct the research is highly acknowledged.

\section{REFERENCES}

Aveling, T. A. S., Snyman, H. G. and Naude, S. P. (1993). Evaluation of seed treatments for reducing Alternaria porri and Stemphylium vesicarium on onion seed. Plant Disease.77: 1009-1011.

Bandi, S. and Sivasubramanian, P. (2012). Management of Thrips tabaci Lindeman in onion using Pseudomonas fluorescens Migula through induced resistance J. Biopest. 5(1): 1-3.

Borkar, S. G. and Patil, B. S. (1995). Chemical control of purple blotch of onion. Indian Journal of Mycology and Plant Pathology. 25 (3): 288-289.

Business Daily. (2013). Purple Blotch, Onion - Kenya: (Rift Valley), Suspected [edited].

Gupta, R. B. L. and Pathak, V. N. (1998). Yield loss in onion due to purple leaf blotch disease caused by Alternaria porri. Phytophylactica. 20: 21-23.

Gupta, R. P.; Srivastava, K. J.; Pandey, U. B. and Midmore, D. J. (1994). Diseases and insect pests of onion in India. Acta Horticulturae. 358: 265-372.

Lawande, K. E.; Mahajan, V.; Sankar, ; Murkute, A.A.;
Mundharikar, D.B.; and Shaikh,H.S.C.(2011). Vision 2030. Directorate of Onion and Garlic Research. Indian Council of Agricultural Research, Rajgurunagar, Pune, Maharashtra. Pp 14.

Mathur, K. and Sharma, S. N. (2006). Evaluation of fungicides against Alternaria porri and Stemphylium vesicarium disease of onion in Rajasthan. J. Mycol. Pl. Pathol. 36(2): 323-324.

Nemane, S. A., Hetmalas, B., Pawar, D. B. and Warde, S. D. (2001). Journal of Maharashtra Agricultural University. 26(3): 347-349.

Schwartz, H. F. and Mohan, S. K. (1995).Compendium of onion and garlic diseases. The American Phytopathological Society Minnesota, USA. Pp54.

Shahnaz, E.; Razdan, V. K.; Andrabi, M. and Rather, T. R. (2013). Variability among Alternaria porri isolates. Indian Phytopathology. 66(2).

Sharma, P. (2012). Trichoderma harzianum (Th-3) a Potential Strain to Manage the Purple Blotch of Onion (Allium cepa L.) Caused by Alternaria porri under North Indian Plains. Journal of Agricultural Science. 4 (10): 266 .

Sharma, S. R. (1986). Effect of fungicidal on purple blotch and bulb yield of onion. Indian Phytopathology. 39: 7882.

Shrivastava, U. (2010). Seventy percent of Maharashtra onion crop damaged, behind crisis:, ICAR, Press Trust of India, New Delhi.

Singh, B. K., Upadhyay, R. K., Singh, S. and Gupta, R. P. (2010). Role of plant extracts, Neem based bio pesticides IGR in management of onion thrips. Presented in National Seminar on "Quality planting material" at New Delhi on March, 11-14, 2010.pp 66.

Suheri, H. and Price, T. V. (2000). Infection of onion leaves by Alternaria porri and Stemphylium vesicarium and disease development in controlled environments. Plant Pathology. 49 (3): 375-382.

Tomar, B. S. and Negi, H. C. S. (2002). Effect of planting time on seed yield, quality characters and disease incidence in onion (Allium cepa L.). In; Proceedings of XI National Seed Seminar on Quality Enhance Agricultural Profitability held at UAS Dharwad, January 18-20, 2002.

Vannaci, G. and Harman, G. E. (1987). Biocontrol of seed borne Alternaria raphani and A. brassicicola. Can. J. Microbiology. 33: 850-856.

Vijaya, M. and Rahman, M. A. (2004). Efficacy of fungicides in control of leaf blight disease of onion (Allium cepa). J. Mycology Pl. Patho. 34(2): 654-655.

Wheeler, B. E. (1969). An Introduction to Plant Diseases. John Wiley and Sons Ltd, London, U. K.

Wickramaarachchi, W. A. R. T., Athauda, A. A. T. R. and Dissanayaka, D. M. K. (2004). Evaluation of selected fungicides for controlling purple blotch disease of small onion. Annals of the Sri Lanka Department of Agriculture. 6: 237-244. 